Универзитет у Београду

Филолошки факултет

aleksandar.ilic.996@gmail.com

\title{
КРАЉ БЕТАЈНОВЕ ИВАНА ЦАНКАРА - СЦЕНСКО ИЗВОЪЕНЕ У ЈУГОСЛОВЕНСКОМ ДРАМСКОМ ПОЗОРИШТУ И ПРИКАЗ ДЕЛА У НАСТАВИ
}

\begin{abstract}
У овом раду анализираће се једна од најзначајнијих драма Ивана Цанкара, „Краљ Бетајнове”, различитим књижевно-теоријским и методичким приступима. Рад ће се састојати из три дела. У уводном делу интерпретираће се сам драмски текст (тематско-мотивски слојеви, композиција, анализа и мотивација главних јунака, функција ироније као доминантне стилске фигуре у Цанкаревом стваралаштву, утицај Шекспира). Други део рада представља осврт на сценско извођење ове драме у Југословенском драмском позоришту у Београду. Завршни део рада је методички. У њему ће се приказати методички ваљана динамика часа на којем ће се тумачити ова Цанкарева драма.
\end{abstract}

Кључне речи: Цанкар, Краљ Бетајнове, драма, позориште, настава

Драма као трећи, најмлађи, књижевни род заузима најмање простора у школском програму из области књижевност. У основној школи углавном се обрађују комедије које су прилагођене узрасту ученика („Капетан Џон-Пиплфокс” Д. Радовић, „Кирија” Б. Нушић, „Избирачица” К. Трифковић, „Покондирена тиква” Ј. С. Поповић, „Сумњиво лице” Б. Нушић). У осмом разреду основне школе обрађује се трагедија „Ромео и Јулија” Вилијама Шекспира. У средњошколском програму драмско стваралаштво добија на значају где се поред комедија („Новела од Станца” М. Држић, „Дундо Мароје” М. Држић, „Тврдица” Ж. Б. Молијер, „Тврдица” Ј. С. Поповић, „Народни посланик” Б. Нушић), трагедија („Антигона” Софокле, „Хамлет” В. Шекспир, „Јелисавета, књегиња црногорска" Ђ. Јакшић) обрађује и драмско стваралаштво у ужем смислу 
(„Ујка Вања” А. П. Чехов, „Краљ Бетајнове” И. Цанкар, „Господа Глембајеви” М. Крлежа, „Чекајући Годоа” С. Бекет).

Гледање позоришне представе је пожељно, али тек након ваљане обраде књижевног дела. Некада се може десити да извођење представе осиромаши утисак ученика, па уместо да га мотивише да прочита дело, оно има супротно дејство. „Имамо у виду да је позоришна изведба само једна сценска интерпретација драмског дела, док је сам његов текст објективна основа за низ могућих, па самим тим и разноликих сценских интерпретација. Зато у школској пракси поред анализе драмског дела, кад год се укаже погодност, ваља анализирати његову позоришну представу, али те две активности не треба мешати, изједначавати и замењивати једну другом" (Николић 2012: 552). На школском часу поред интерпретације драмског текста ваља извести и драматизацију текста који се обрађује. На тај начин ћемо укључити и оне ученике који су мање заинтересовани, а ученике који нису прочитали дело мотивисаћемо да дело прочиатају.

Драма „Краљ Бетајнове” објављена је 1902. године, прожета је социјалном свешћу. Спада у грађанске драме у ужем смислу. Догађа се у јесен у варошици Бетајнови. Драма започиње Максовим повратком у варошицу Бетајнову. Он је студент филозофије, револтиран животом. Његов отац, пропали крчмар Крнец, се пропио, па му је Кантор све узео. Макс је обескорењени јунак, јер га интелект обавезује да буде грађанин целог света. Због тога је он модернистички јунак. Кантор је фабрикант и зеленаш који влада читавим местом. Агресиван је и инвезиван. У Канторовом изражавању јавља се огољеност, самоименовање у „краља краљевства”. Под влашћу је подсвесног. Пати од несанице, јер није имун на моралне императиве. Макс је пасиван јунак, не дела, већ моралом покушава да утиче на Кантора. Њему је сличан Франц Бернот, студент технике. Они су у овој малограђанској средини једини прави интелектуалци, али се разликују у животним погледима, јер Бернот жели угодан, миран и спокојан живот, без узнемиравања.

Кључни мотив јесте мотив убиства. Кантор је убио свог брата и то чува као најдубљу тајну. Овде се јавља шекспировски мотив „мишоловке”, преузет из трагедије „Хамлет”. Макс се појављује као хламлетовска фигура, јер је неодлучан. Ова сцена је значајна јер буди Канторову савест. Та сцена представља „позориште у позоришту” и средиште је драмског заплета. Макс прети да ће га 
разоткрити, да зна за његову тајну. Максов циљ је да демаскира Кантора, да га прикаже као злочинца, али истовремено жели да у Кантору пробуди људску савест. Кантор је спреман да призна кривицу, на самој је ивици признања. Инсценација злочина је у души злочинца изазвала страх. Насупрот страху стоји његова дијалктичка супротност - воља за моћ. Воља за моћ, похлепа за богатством и жеђ за влашћу чине примарни тематски слој дела. На крају драме јавља се обрт, израз Цанкареве ироније, Кантор позива судију да призна злочин, а судија га убеђује да ништа о томе не говори. Кантор је убио Макса Францовом пушком и због тога сва сумња пада на Франца. Кантор прихвата да није крив. Он је спреман на покајање и прочишћење, али друштво није, друштво је оболело и за њега нема спаса. И тек сада Кантор схвата суштину своје друштвене моћи и неограниченост, ослобађа се савести и страха.

Cyguja: „Ko їа је убио?”

Канйор: ,Ja!”

Суgија: „Канйоре, јеси ли йолуgео? Данас се са вама не може

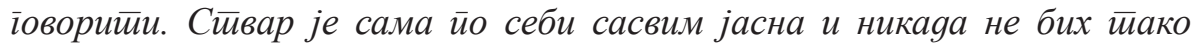
нешито йомислио о йом ироклетиом Бернойу."

Канйор: „На сваки начин, значи, убио іа је Берноти и нико яруіи ни ја, нитии ико gруіи? (Цанкар 1978: 66)

После седамдесет година од прве изведбе, ово дело поново је постављено на сцену Југословенског драмског позоришта. То је била прва представа у новооснованом позоришту које је окупљало глумце из читаве бивше Југославије. Поновном поставком, у режији Милана Нешковића, обележен је јубилеј ове куће.

Редитељ је одлучио да осавремени Цанкареву драму, па је радњу сместио у данашње време. Дела која су класици могу се поставити у било које време, јер су питања која покрећу увек актуелна. Да ли је то случај са овом драмом? Да ли је њена тема актуелна и данас? То је прво питање са којим се морамо суочити. Ова одлука веома је смела, јер драма осликава време са самог краја деветнаестог века, када се полако рађа радничка класа која покушава да се супродстави моћним капиталистима које оличава Кантор. Данас радничка класа одумире, социјализам је нестао са распадом државе, а завладао је суров капитализам. Нису више актуелни јунаци као што је Макс Крнец, док ће ликови попут Кантора у сваком друштву опстати. Ако се редитељ одлучио да осавре- 
мени поставку, требало је до краја бити истрајан у тој замисли, те је морао извршити неке иновације и уклонити сувишна лица. На првом месту то је Лужарица, жена радника кога је Кантор отпусио јер је учествовао у штрајку. Ова јунакиња припада социјалном тематском слоју драме који је био актуелан у време настајања драме. Значајно место у драми заузима лик жупника. У деветнаестом веку, у католичкој средини, жупници су имали улогу просветитеља. Они су били ти који штите морал и прокламују праве животне вредности. Код Цанкара овај лик је предмет ироније, јер уместо да злочинца натера на покајање, он га убеђује да ништа није згрешио. Приказана је његова корумпираност и превртљивост. Ове карактерне особине испољене су и на сцени, па је овај лик сведен на гротескну појаву, јер носи црвене патике. На тај начин је приказано потпуно урушавање свештенства, које редитељ доводи до бурлеске. Редитељ уводи и лик надзорника који Канора наводи да злочин свали на Франца Бернота. Један од ова два лика је овде сувишан. Који? То би био лик жупника јер у савременом друштву утицај цркве знатно опада.

Лик Макса је недоречен. Није приказан као антималограђански интелектуалац, већ као бунтовни и незрели младић. Веома слично приказан је и Франц Бернот, само знатно инфантилније. Главни јунак, Кантор, представљен је као гротескна фигура. На тренутке комичан, а на тренутке трагичан. Сцена која би требало да представља кулминацију јесте убиство Макса, јер она у читаоцу буди језу и страх. У овом извођењу она делује бизарно - задавивши га, Кантор Максово мртво тело убацује у акваријум у коме му задаје хитац пушком, па се крв разлије и замути воду. Још једна неуспела сцена јесте инсценација убиства Нининог оца. Она је у тексту представљена по узору на шекспировски мотов ,мишоловке” из „Хамлета”, у којој Максов отац игра Нининиг оца. На сцени нема „мишоловке”, већ Макс дави сам себе како би у Кантору пробудио савест. Сцене између Макса и Францке сувише су банализоване, њихова љубав сведена је углавном на еротско.

Ученик ако ову представу одгеледа пре тумачења самог текста, може бити знатно спутан при читању, тумачењу и разумевању текста. Да његова имагинација не би била нарушена представу је најбоље одгледаи након обраде дела у школи. На редовном часу или часу драмске секције ученик ће изнети своје утиске о представи и компаративном методом уочити сличности и разлике између књижевног дела и његове сценске интерпретације. 


\section{Тумачење дела у настави; Динамика часа}

Наст̄авна јеgиница: Анализа драме „Краљ Бетајнове” Ивана Цанкара

Тий часа: Обрада градива Облик раgа: Фронтални

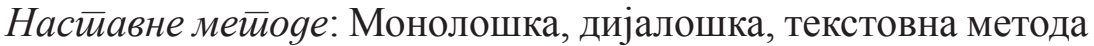

Настиавна среgстива: Читанка, креда, табла

Корелаиија: Ванпредметна, са сценском уметношћу

Образовни ичиљеви: Оспособљавање ученика за тумачење драмског текста. Упознавање ученика са појмом драма у ужем смислу. Издвајање композиционих етапа драме. Детаљно анализирати главне јунаке. Откривање вишеслојности драмске радње.

Васииитини ичиљеви: Неговање моралних вредности код ученика. Оспособљавање ученика за поуздано морално расуђивање. Опрдељавање за добро и осуда тираније, зла, неморала. Развијање свести код ученика о значају контроле мржње и гнева. Развијање способноси саосећања са судбином јунака.

Функционални цильеви: Богаћење ученикове маште и увођење у симболику простора. Развијање смисла за откривање битних детаља. Подстицање ученика да самостално закључују, да се слободно изражавају, да одгледају истоимену позоришну представу у Југословенском драмском позоришту.

Увояни део часа:

Припремни разговор са ученицима за анализу драме „Краљ Бетајнове":

Присетите се својих знања о Ивану Цанкару из основне школе. Подсетите се приповетке коју сте обрађивали у основној школи? Издвојте неке од уметничких особина Цанкаревог стваралаштва.

Од ученика се очекује да се присете раније обрађиване приповетке „Десетица”, која је предвиђена за обраду у петом разреду основне школе. Ученици се присећају тешких психолошких стања главног јунака које нам је аутор тако живо приказао. Издвајају особине реалистичког приповеања које добија обележја модернизма.

Главни део часа:

Обратите пажњу на композицију драме. Које тематске слојеве уочавате? Ко су главни актери? Образложите у каквим су међусобним односима. Покушајте да се присетите којим моделом је изведена инсценација убиства Нининог оца у драми. 
Цанкар је ову драму градио на сукобу капиталистичког моћника Кантора и студента Макса Крнеца. Вративши се са студија у зваичај, Макс затиче знатне промене. Његов отац је материјално сасвим пропао, имање је купио Кантор, а стари Крнец се у очајању пропио. Макс је човек напредних схватања, близак радничкој класи. У Бетајнови нема радничке класе, има сиротиње, надничара, слугу, али то није још увек она друштвена снага која би се могла супродставити моћном Кантору. Зато Макс полази сам у борбу против овог злобника.

Социјалном тематиком плану драме припада и Лужарица, жена радника кога је Кантор отпустио јер је учествовао у штрајку. Лужарица се на сцени увек појављује са децом, долази да моли Кантора да помилује њеног мужа. Хана ће је заштитити.

Психолошко и морално у „Краљу Бетајнове” тешко се може издиференцирати. Многе се моралне дилеме рефлектују као конкретна психолошка стања. Пуно је и приметних и неприметних драма које се збијају у душама јунака. Унутрашње биће Макса и Кантора одређено је нечим што је изван њихове воље.

Једна од најсуптилнијих сцена психолошке природе јесте Максово режирање сцене у којој је Кантор задавио свога брата, Нининог оца. Инсинуација је била толико успешна да се Кантор доиста ухватио у ову мрежу, изведе оне исте убилачке покрете од пре четири године (крене да дави овог пута Максовог оца, који у овом „комаду у комаду" игра Нининог оца). Кантор је погођен оваквим својим понашањем, за тренутак помисли да је свему крај, обузима га страх да му сада преостаје још само срамни гроб који ће сви пљувати.

Пратите како се у драми наговештава и развија драмски сукоб. Задржите се на појединостима којима је дочарана атмосфера. Тумачите Максов лик. Запазите и објасните који је Максов крајњи циљ. На који начин је обликован лик злочинца? Има ли у њему савести? Да ли јунак признавши злочин доживљава прочишћење?

Драмски сукоб одиграва се на моралном плану. Макс је вођен поносом и осветољубивошћу. Макс каже : Кад видим таквог силника, ухвати ме страховита жеља да га уједем за ногу (Цанкар 1978: 32). Ујести некога за ногу у том крају Словеније значи понизити га. Макс у својој борби против силништва и аморала не тежи уништењу противника него његовом понижењу, а пут ка понижењу према Максовом схватању, преко демаскирања и раскринкавања Кантореве личности, иде ка кажњавању његове свести. У томе би и била Максова освета. 
Први Максов корак ка буђењу Канторове савести је инсценација убиства Нининог оца. Нина је једини сведок Канторевог злочина и зато он жели да је склони у манастир. Реконструкција злочина изазвала је у њему страх, али савест се још увек није пробудила. Уплашени Кантор пита Макса ко ће му скинути круну с главе и истргнути железо из руку, Макс одговара: „Ја!” И баш то је дало снагу Кантору да савлада страх који осећа. Кантор у тренутку када схвата да је Макс сам одлучује да га убије. То и чини на очиглед своје породице.

На почетку трећег чина Кантор је опет запао у моралну кризу јер је осетио да га се сви у породици боје. Пружа руку да помилује сина по глави, а дете са језом гледа његову руку која је држала пушку и убила Макса.

Канторов лик је грађен у строгој зависности од средине, простора и времена. Он је схватио да га мишљење и став других људи конституише као поштеног човека, а не као убицу. Ово се показује када судија отписује сваку могућност Канторове кривице.

Заврини део часа:

Каква је симболика завршетка драме? Објасните како је приказан људски живот у драми. Које идејне перспективе можете издвојити?

Кантор, признавши злочин, спреман је на прочишћење, али дрштво није спремно. Друштво је оболело и за њега нема спаса.

Драма „Краљ Бетајнове” је и морална и социјална, прати сукоб два лика, две индивидуе, али и сукоб једине и друштва. У њој је додирнут и комплекс љубави. У начину вођења радње преплићу се две технике, од класичне шекспировске „игре у игри” до елемената криминалистичке драме. Ова драма најближа је трагедији - сукобљавају се припадници двеју етичких принципа. И Макс и Кантор су у власти ирационалних сила и понашају се као што им налаже та виша сила, којом су обузети. Кантор је човек који је у власти воље за моћ, а Макс воље за праведношћу.

Макс је заокупљен етосом солидаран са жртвама насиља, позитиван и несумњив морални победник. Иако је Макс још увек индивидуални борац против дуршвеног неморала, у драми се појављује и пролетеријат. Супротност између ова два јунака се може разумети као класна и социјална супротност. То су одјеци социјалистичких идеја са којима се Цанкар упознао у Бечу. Из идејне перспективе израста сатира.

На крају часа наставник даје упутства за домаћи задатак и додатна истраживања: 


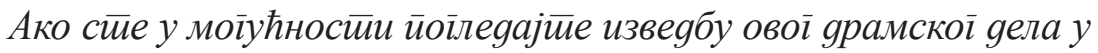

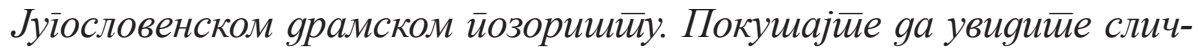

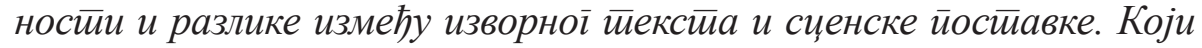
йлумаи вам је најбоље gочарао свој лик? Да ли бисте ви gруїачие йостиавили ову gраму? Шйа бисте изменили? Образложите gа ли вам се више gойаgа књиі̄а или йреgстисава. Арїуменйујйе свој оgїовор.

\title{
Литература
}

Иван ЦАНКАР, 1978: Краљ Бетајнове, Београд: Нолит

Милија НИКОЛИЋ, 2012: Методика наставе српског језика и књижевности, Београд: Завод за уџбенике

Марија МИТРОВИЋ, 1995: Преглед словеначке књижевности, Сремски Карловци, Нови Сад: Издавачка књижница Зорана Стојановића

\section{Aleksandar Ilić}

\section{THE KING OF BETAJNOVA BY IVAN CANKAR - STAGE PERFORMANCE IN YUGOSLAV DRAMA THEATRE AND INTERPRETATION OF THE BOOK IN CLASS}

\author{
Summary:
}

In this paper, one of the most important dramas by Ivan Cankar, The king of Betajnova, will be analysed in different literary, theoretical and methodical approaches. The paper will contain three parts. In the introduction, the text of the play will be interpreted (theme and motivs, composition, analysis and motivation of the main characters, function of irony as dominant figure of speech in Cankar's work, the influence of Shakespeare). Second part of the paper is review of the stage performance of this drama in Yugoslav drama theatre in Belgrade. Final part of the paper is methodical. In it, I will present methodically valid dynamic of the class in which this drama will be interpreted.

Key words: Cankar, The king of Betajnova, theatre, drama, class 